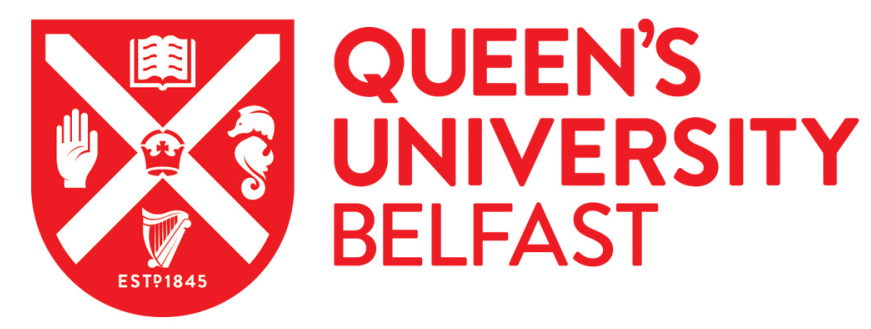

\title{
Inorganic arsenic removal in rice bran by percolating cooking water
}

Signes-Pastor, A. J., Carey, M., \& Meharg, A. A. (2017). Inorganic arsenic removal in rice bran by percolating cooking water. Food Chemistry, 234, 76-80. https://doi.org/10.1016/j.foodchem.2017.04.140

\author{
Published in: \\ Food Chemistry
}

Document Version:

Version created as part of publication process; publisher's layout; not normally made publicly available

Queen's University Belfast - Research Portal:

Link to publication record in Queen's University Belfast Research Portal

\section{Publisher rights}

Copyright 2017 Elsevier.

This manuscript is distributed under a Creative Commons Attribution-NonCommercial-NoDerivs License

(https://creativecommons.org/licenses/by-nc-nd/4.0/), which permits distribution and reproduction for non-commercial purposes, provided the author and source are cited.

\section{General rights}

Copyright for the publications made accessible via the Queen's University Belfast Research Portal is retained by the author(s) and / or other copyright owners and it is a condition of accessing these publications that users recognise and abide by the legal requirements associated with these rights.

Take down policy

The Research Portal is Queen's institutional repository that provides access to Queen's research output. Every effort has been made to ensure that content in the Research Portal does not infringe any person's rights, or applicable UK laws. If you discover content in the Research Portal that you believe breaches copyright or violates any law, please contact openaccess@qub.ac.uk. 
1 Inorganic arsenic removal in rice bran by percolating cooking water

3 Antonio J. Signes-Pastor*,a , Manus Carey, Andrew A. Meharg

5 Institute for Global Food Security, Queen's University Belfast, David Keir Building,

6 Malone Road, Belfast, BT9 5BN, Northern Ireland.

$8 *$ Corresponding author

9 Email: antonio.j.signes-pastor@dartmouth.edu

10 acCurrent address: Department of Epidemiology, Geisel School of Medicine,

11 Dartmouth College, 1 Medical Center Dr, 7927 Rubin Bldg, Lebanon, NH03766, 12 USA

\section{Abstract}

15 Rice bran, a by-product of milling rice, is highly nutritious but contains very high

16 levels of the non-threshold carcinogen inorganic arsenic (i-As), at concentrations

17 around $1 \mathrm{mg} / \mathrm{kg}$. This i-As content needs to be reduced to make rice bran a useful

18 food ingredient. Evaluated here is a novel approach to minimizing rice bran i-As

19 content which is also suitable for its stabilization namely, cooking bran in percolating

20 arsenic-free boiling water. Up to $96 \%$ of i-As removal was observed for a range of

21 rice bran products, with i-As removal related to the volume of cooking water used.

22 This process reduced the copper, potassium, and phosphorus content, but had little

23 effect on other trace- and macro- nutrient elements in the rice bran. There was little

24 change in organic composition, as assayed by NIR, except for a decrease in the

25 soluble sugar and an increase, due to biomass loss, in dietary fiber. 
26

27 Keywords: inorganic arsenic, rice bran, cooking water, nutrient elements, and rice 28 bran composition. 


\section{Introduction}

30 Rice bran has high concentration in micro- and macro nutrient elements, vitamins and

31 soluble fiber, and is considered a good source of hypoallergenic protein (Zhang, 32 Zhang, Wang, \& Guo, 2012). It is becoming a popular ingredient in health-promoting 33 value-added products, it is marketed as a superfood, and has been considered as a 34 health food supplement for malnourished children in international aid programs among other applications (Nagendra Prasad MN, Kr, \& Khatokar M, 2011; Qureshi, Sami, \& Khan, 2002; Sun et al., 2008; Zhang et al., 2012). However, the realization that rice bran also contains high levels of the carcinogen inorganic arsenic (i-As) (Andrew A. Meharg et al., 2008; Sun et al., 2008), has stalled the development of the utilization of this otherwise very valuable product.

41 Rice accumulates much higher levels of i-As than other cereals and foodstuff, in 42 general, due to being cultivated in flooded soils (A. A. Meharg \& Zhao, 2012; Sun et 43 al., 2008; Williams et al., 2007). In rice grain most of the i-As is accumulated in the 44 outer bran layers, the pericarp and the aleurone, having i-As concentrations as high as $45<1 \mathrm{mg} / \mathrm{kg}$ (Andrew A. Meharg et al., 2008; Sun et al., 2008). The European Union has 46 formulated regulations on the maximum levels of $\mathrm{i}$-As in rice in order to reduce 47 exposure, and the most restrictive one has been established at $0.1 \mathrm{mg} / \mathrm{kg}$ for rice 48 destined for the production of food for infants and young children, the level of which 49 has also been recently proposed as a maximum limit in infant rice cereals by the U.S. 50 Food and Drug Administration (EC, 2015; FDA, 2016). The UN WHO has also set an 51 advisory maximum level of $\mathrm{i}-\mathrm{As}$ in polished rice grain at $0.2 \mathrm{mg} / \mathrm{kg}$ (WHO, 2014), 52 which is also the EU standard. Fortification with rice bran has become popular in 53 health/organic/whole-meal foodstuffs, and such rice bran fortified foods, such as 
54 baby/toddler foods, tend to be elevated in i-As, leading them to have i-As concentrations above EU standards, for example (Signes-Pastor et al., 2016).

Previous studies have shown that $\mathrm{i}$-As in rice is quite soluble in cooking water, and that the larger the volume of cooking water used the greater the i-As removal (Raab,

59 Baskaran, Feldmann, \& Meharg, 2009). The method of cooking rice might enable i60 As mitigation, especially when low i-As cooking water is available (Carey, Jiujin, 61 Gomes Farias, \& Meharg, 2015). Carey et al. (2015) developed this observation to pioneer a novel approach to rice cooking to maximize i-As removal. Their findings showed that if rice was percolated with clean, i.e. i-As free, cooking water, up to $85 \%$ of i-As could be removed from rice grains while cooking. The percolated cooking water was either recycled (as steam then condensed to form percolating water) or discarded. In the study reported here the efficacy of such percolating cooking technologies in removing i-As from rice bran was trialed. Key to this study was that this cooking of whole rice bran had minimal impact on the beneficial nutritional qualities of bran such as fiber, protein and mineral nutrient content.

\section{Material and Methods}

\subsection{Rice bran cooking}

73 Commercial rice bran samples (16) were purchased, including pure rice bran $(\mathrm{n}=14)$

74 and rice bran water-soluble $(\mathrm{n}=2)$ products. An off-the-shelf coffee percolator by

75 Andrew James, with no adaptation, was used to cook rice bran, as per Carey et al.

76 (2015). This type of coffee-maker provides a continual stream of percolating, near

77 boiling, water through a filter unit. Here, the water reservoir was filled with $1.5 \mathrm{~L}$ of

78 deionized water, which took $15 \mathrm{~min}$. to fully discharge through the filter unit. In the 
metal-mesh filter unit $20 \mathrm{~g}$ of bran was placed. The bran samples were then cooked in 1- $415 \mathrm{~min}$. cycles with the reservoir re-filled at the end of each cycle, water-to-rice bran ratios of which were $75: 1,150: 1$ and 300:1, respectively.

\subsection{Sample preparation and chemical analysis}

The raw and cooked rice bran samples were freeze-dried using a Christ Alpha 1-4 LD Plus, and then powdered using a Retch PM100. The powder was used for X-ray fluorescence (XRF) and near infrared (NIR) spectroscopy analyses. For arsenic speciation powdered sample, $0.1 \mathrm{~g}$, was accurately weighed into $50 \mathrm{ml}$ polypropylene centrifuge tubes and $10 \mathrm{ml}$ of $1 \%$ concentrated nitric acid was added and left overnight. Then samples were microwave digested in a CEM MARS 6 instrument for $30 \mathrm{~min}$. at $95^{\circ} \mathrm{C}$ using a 3 stage slow heating program: to $55^{\circ} \mathrm{C}$ in $5 \mathrm{~min}$. held for 10 min., to $75^{\circ} \mathrm{C}$ in $5 \mathrm{~min}$., held for $10 \mathrm{~min}$. to $95^{\circ} \mathrm{C}$ in $5 \mathrm{~min}$., held for $30 \mathrm{~min}$. The digestate was centrifuged with a Sorvall Legend $\mathrm{RT}$ at 4,500 $\mathrm{g}$ and a $1 \mathrm{ml}$ aliquot was transferred to a $2 \mathrm{ml}$ polypropylene vial and $10 \square 1$ of analytical grade hydrogen peroxide was added to convert any arsenite to arsenate to facilitate subsequent chromatographic species separation by ion chromatography with mass spectrometric detection (IC-ICP-MS). All samples were analyzed in 2 batches including 3 blanks and 3 replicate samples of the certified reference material (CRM) NIST $1568 \mathrm{~b}$ rice flour per batch. For total element analysis by inductively coupled plasma - mass spectrometric (ICP-MS) $2 \mathrm{ml}$ of concentrated nitric acid and $2 \mathrm{ml}$ of hydrogen peroxide were added into $50 \mathrm{ml}$ polypropylene centrifuge tubes containing $0.1 \mathrm{~g}$ of powdered sample and left to stand overnight. The samples were microwave digested. The temperature was raised to $95^{\circ} \mathrm{C}$ in $5 \mathrm{~min}$. and held for $10 \mathrm{~min}$. and then to $135^{\circ} \mathrm{C}$ in $5 \mathrm{~min}$. and held for $10 \mathrm{~min}$. Finally the digest was taken up to $180^{\circ} \mathrm{C}$ in $5 \mathrm{~min}$. and 
maintained for $30 \mathrm{~min}$. Samples were cooled to room temperature and then an internal standard (30 $\mu \mathrm{l}$ of $10 \mathrm{mg} / \mathrm{kg}$ rhodium) was added to the digestate and accurately diluted to $30 \mathrm{ml}$ with deionized distilled water. Several blanks and samples of NIST $1568 \mathrm{~b}$ rice flour CRM were included per batch of total element analysis.

109 A Thermo Scientific IC5000 ion chromatography (IC) system, with a Thermo AS7, $1102 \times 250 \mathrm{~mm}$ column and a Thermo AG7, 2x50 mm guard column interfaced with a

111 Thermo ICAP Q ICP-MS in collision cell mode was used to quantify arsenic

112 speciation. A linear gradient mobile phase was carried out over 15 minutes starting at

$113100 \%$ mobile phase of $20 \mathrm{mM}$ ammonium carbonate and finishing at $100 \%$ mobile

114 phase of $200 \mathrm{mM}$ ammonium carbonate. The resulting chromatogram was compared 115 with that for authentic standards; dimethylarsinic acid (DMA), i-As,

116 monomethylarsonic acid (MMA), tetratmethylarsonium and arsenobetaine. DMA

117 concentration series were used to calibrate the arsenic present under each

118 chromatographic peak.

120 Total elements were also measured using the Thermo ICAP Q but in direct solution 121 acquisition mode. All elements reported were present both in calibration standards 122 and in CRM NIST $1568 \mathrm{~b}$ with only elements with good CRM recoveries reported. 123 Additional elements were also analyzed by bench-top XRF (Rigaku CG), including 124 samples of NIST $1568 \mathrm{~b}$ rice flour CRM in each batch of samples. Only elements 125 present in the CRM and with good analytical recoveries were presented. Rice bran 126 composition was also analyzed with a Thermo near infrared (NIR) spectroscopy. Each 127 rice bran samples was analyzed in triplicate and the mean value was used to calculate 128 the percentage of compositional variation of individual samples. 


\subsection{Statistical analyses}

131 The median and range concentration of the main arsenic species in commercial rice 132 bran samples were determined. Likewise, total elements concentration $(\mathrm{Ca}, \mathrm{Cu}, \mathrm{Fe}$, $133 \mathrm{Mn}, \mathrm{P}$ and $\mathrm{S}$ ) and the percentage of the rice bran organic composition variation (fat, 134 fiber, protein, starch and sugar) according to the cooking percolating water-to-rice 135 bran ratio was also analyzed. The analysis of variance (ANOVA) and the Tukey's 136 range test were used to determine any significant differences in the main arsenic 137 species and total elements concentration between groups according to the volume of 138 percolating cooking water. All statistical analyses and plots were performed using the

139 R Statistical Software (R Core Team, 2014). The limit of detection (LOD) was 140 calculated as the mean of the blank concentrations plus three times the standard 141 deviation of the blank concentrations multiplied by the dilution factor. The $1 / 2$ LOD 142 value was assigned for statistical analyses of the data when samples were below the 143 LOD.

\section{Results}

146 The mean \pm SE concentration and recovery of rice CRM flour NIST-1568b for 147 arsenic species were: $0.099 \pm 0.001 \mathrm{mg} / \mathrm{kg}$ and $107 \pm 2 \%$ for i-As, $0.184 \pm 0.007$ $148 \mathrm{mg} / \mathrm{kg}$ and $102 \pm 4 \%$ for DMA, and $0.010 \pm 0.001 \mathrm{mg} / \mathrm{kg}$ and $89 \pm 3 \%$ for MMA, 149 based on $\mathrm{N}=6$. The arsenic species in the rice CRM had $\mathrm{i}-\mathrm{As}$, DMA and MMA 150 certified at $0.092 \pm 0.010 \mathrm{mg} / \mathrm{kg}, 0.182 \pm 0.012 \mathrm{mg} / \mathrm{kg}$, and $0.0116 \pm 0.0035 \mathrm{mg} / \mathrm{kg}$, 151 respectively. The limit of detection (LOD) for arsenic speciation, calculated from 152 DMA calibration, was $0.002 \mathrm{mg} / \mathrm{kg}$. All samples presented were above the LOD for 153 DMA and i-As, however, almost half of the rice bran samples analyzed had MMA 
content below the LOD, and in this case $1 / 2$ LOD was used in statistical analysis of the data.

The predominant arsenic species in the commercial rice bran samples analyzed was i-

As, followed by DMA and MMA (Table 1). The median and range percentage of $\mathrm{i}$-As in the entire commercial raw/uncooked rice bran dataset were $95.4 \%$ and $93.4 \%-$ $97.7 \%$, respectively. The commercial rice bran water-soluble samples, obtained with the carbohydrases treatment (Qureshi et al., 2002), had 1.6-fold higher median i-As $(0.916 \mathrm{mg} / \mathrm{kg})$ than that found in uncooked pure rice bran $(0.561 \mathrm{mg} / \mathrm{kg})$. The DMA concentration in uncooked rice bran was about an order of magnitude lower than that

164 of $\mathrm{i}$-As, with a median of $0.025 \mathrm{mg} / \mathrm{kg}$ and a range from 0.013 to $0.055 \mathrm{mg} / \mathrm{kg}$ for the entire commercial uncooked rice bran dataset. Only $\sim$ half of the commercial raw rice bran dataset had traces of MMA higher than the LOD, with a median of $0.003 \mathrm{mg} / \mathrm{kg}$ ranging from $<$ LOD to $0.006 \mathrm{mg} / \mathrm{kg}$.

The i-As concentration in cooked rice bran was significantly lower compared to that in the uncooked rice bran $(p<0.001)$ (Table 2). This study shows that greater i-As

171 removal from cooked rice bran can be achieved with greater water-to-rice bran ratio,

172 but only up to a certain extent (Table 2 and Figure 1). The i-As concentration in 173 cooked rice bran with 150:1 and 300:1 water-to-rice bran ratios did not differ

174 statistically (Table 2). A median percentage of $68 \%$ and $76 \%$ of i-As could be 175 removed at the highest water-to-rice bran ratios (150:1 and 300:1, respectively), and 176 even higher than $90 \%$ in some individual samples (Figure 1). The DMA

177 concentration in cooked rice bran was significantly lower compared with that in the 178 uncooked rice bran $(p<0.001)$, however, the volume of cooking water did not affect 
statistically the DMA concentration in the cooked rice bran (Table 2). A median percentage of $52 \%, 62 \%$ and $65 \%$ of DMA could be removed at $75: 1,150: 1$ and 300:1 water-to-rice bran ratios, respectively (Figure 1). The cooking process did not affect the MMA concentration in the rice bran. The MMA traces found in the uncooked samples were still found in the cooked rice bran regardless of the volume of the cooking water tested.

When a range of trace- and macro- elements were analyzed between uncooked and cooked rice bran with different volumes of cooking water, only copper $(p=0.002)$, potassium $(p<0.001)$, and phosphorus $(p<0.001)$ were significantly different, while calcium, iron, manganese, sulfur and zinc were non-significant (Table 2). The loss of copper, potassium and phosphorus during the cooking process was $37 \%, 54 \%$ and $16 \%$, respectively, regardless of cooking water volume tested, which did not statistically affect the concentration of these elements in the cooked rice bran (Table 2).

When the compositional variation in rice bran due to the cooking process with different volumes of water was explored only the fiber and the sugar content seemed to differ from the original content in the uncooked rice bran, while fat, protein and starch appeared to be stable throughout the cooking process regardless of the volume of cooking water (Figure 2). The fiber content in cooked rice bran had a median percentage increment of $14 \%, 35 \%$, and $40 \%$ compared to that in uncooked rice bran when 75:1, 150:1 and 300:1 water-to-rice bran ratios were performed, respectively, increment of which is probably due to the overall rice bran biomass decrease caused during the cooking process. On the contrary, the relationship between fiber and sugar 
had a negative correlation coefficient of -0.63 , with a median percentage reduction of sugar content of $35 \%, 57 \%$, and $82 \%$ according to the level of percolating cooking water volume.

\section{Discussion}

209 Rice bran has become a popular ingredient in "health-products" due to its positive 210 nutritional aspects. However, rice bran contains high concentrations of i-As, up to 1.1

$211 \mathrm{mg} / \mathrm{kg}$ in this study here, which needs to be reduced to make rice bran suitable for the 212 human consumption. Using a continuous flow of arsenic-free near boiling water 213 percolated through pure rice bran enables an i-As removal from rice bran of up to $21496 \%$, a higher percentage than that previously reported for whole-grain and polished 215 rice samples where a maximum removal value of $85 \%$ was obtained for individual 216 rice samples (Carey et al., 2015). This may be related to the larger cooking water-to217 rice bran ratio used in this study (i.e. 300:1) compared to that previously tested with 218 rice (i.e. 12:1). A moderation of i-As removal efficiency from rice bran was described

219 for the higher volumes of cooking water, reaching a plateau at a cooking water-to-rice 220 bran ratio of 150:1. The i-As removal approach described here provides a novel 221 solution to significantly reduce the i-As concentration in pure rice bran below the UN 222 WHO advisory level and the maximum EU i-As limit for non-parboiled milled rice $223(0.200 \mathrm{mg} / \mathrm{kg})$. A patented methodology to remove arsenic in rice bran protein has 224 been previously developed in China; however, the patent differs from the approach 225 detailed in this study focused on i-As removal from whole rice bran instead of from 226 the subcomponent rice bran protein. In addition, the patented approach is for an 227 industrial setting, and combines a static cooking chemical extraction with sodium 228 hydroxide at pH 11.5 and a centrifugation step (China Faming Zhuanli Shenqing, 
2013). Conversely, the approach described here can be applied from a

home/homestead to an industrial setting, and only uses pure water in a continuous novel percolation cooking technique.

The heat involved in cooking may stabilize the rice bran by destruction or inhibition of lipase - the enzyme that causes development of free fatty acids responsible for rancidity, which would save including an extra process to stabilize the rice bran (Nagendra Prasad MN et al., 2011). This remains to be tested along with the effect of the cooking process on the sensorial features of the final rice bran, i.e. texture and color; however, moist heat stabilization is one of the methods used in the normal rice bran processing before its use (Kim, Chung, \& Lim, 2014; Lakkakula, Lima, \& Walker, 2004; Patil, Kar, \& Mohapatra, 2016).

The removal approach reduced the copper, potassium and phosphorus content in the cooked rice bran; however, the concentrations of these elements were still very high compared to that found in rice (Carey et al., 2015), and if necessary, they could be refortified after cooking process. The i-As removal approach described here also reduced the soluble sugar content in favor of an increment of insoluble dietary fiber in treated rice bran, possibly due to the decrease in biomass. This could help in creating healthier food products due to the cooked brans lower sugar and higher fiber content (The Lancet, 2016; Wang, Suo, de Wit, Boom, \& Schutyser, 2016). Neither vitamins nor other bioactive compounds removed due to rice bran processing with percolating near boiling water were assessed here, and thus further studies are required to address this, especially for those water-soluble and thermo sensitive, i.e B-vitamins group and phenolic compounds, which rice bran contains in notable amounts (Kim \& Lim, 2016; 
254 Patil et al., 2016; Tuncel, Yilmaz, Kocabiyik, \& Uygur, 2014). Again, if key vitamins 255 are remove, these could be refortified if necessary.

256

257 The approach studied here demonstrates that the continual percolating of near boiling 258 cooking water flow principle is an efficient i-As whole rice bran removal method. The 259 high volumes of water used here could be greatly reduced if the cooking water was 260 recycled through distillation by using the previously validated for i-As removal from 261 rice grain (Carey et al., 2015).

263 Acknowledgment

264 This work was funded by a Marie Curie Intra-European Fellowship within the $7^{\text {th }}$

265 European Community Framework Programme (PIEF-GA-2013-622096). 
Carey, M., Jiujin, X., Gomes Farias, J., \& Meharg, A. A. (2015). Rethinking Rice Preparation for Highly Efficient Removal of Inorganic Arsenic Using Percolating Cooking Water. Plos One, 10(7), e0131608. http://doi.org/10.1371/journal.pone.0131608

China Faming Zhuanli Shenqing. (2013). One for the removal of arsenic in rice bran method. Retrieved from https://patentimages.storage.googleapis.com/pdfs/5b58c5d309eeb9a5b3ff/CN10 3461646B.pdf

EC. (2015). Commission Regulation 2015/1006 of 25 June 2015 amending Regulation (EC) No 1881/2006 as regards maximum levels of inorganic arsenic in foodstuffs. Retrieved from eur-lex.europa.eu/legalcontent/EN/TXT/?uri=OJ:JOL_2015_161_R_0006

FDA. (2016). FDA proposes limit for inorganic arsenic in infant rice cereal. Retrieved from http://www.fda.gov/newsevents/newsroom/pressannouncements/ucm493740.htm

Kim, S., Chung, H., \& Lim, S. (2014). Effect of various heat treatments on rancidity and some bioactive compounds of rice bran. Journal of Cereal Science, 60(1), 243-248. http://doi.org/10.1016/j.jcs.2014.04.001

Kim, S., \& Lim, S. (2016). Enhanced antioxidant activity of rice bran extract by carbohydrase treatment. Journal of Cereal Science, 68, 116-121. http://doi.org/10.1016/j.jcs.2016.01.006

Lakkakula, N. R., Lima, M., \& Walker, T. (2004). Rice bran stabilization and rice bran oil extraction using ohmic heating. Bioresource Technology, 92(2), 157161. http://doi.org/10.1016/j.biortech.2003.08.010

Meharg, A. A., Lombi, E., Williams, P. N., Scheckel, K. G., Feldmann, J., Raab, A., ... Islam, R. (2008). Speciation and localization of arsenic in white and brown rice grains. Environmental Science \& Technology, 42(4), 1051-1057. http://doi.org/10.1021/es702212p

Meharg, A. A., \& Zhao, F. J. (2012). Arsenic \& Rice. Berlin: Springer-Verlag.

Nagendra Prasad MN, N. P., Kr, S., \& Khatokar M, S. (2011). Health Benefits of Rice Bran - A Review. Journal of Nutrition \& Food Sciences, 1(3), 1-7. http://doi.org/10.4172/2155-9600.1000108

Patil, S. S., Kar, A., \& Mohapatra, D. (2016). Stabilization of rice bran using microwave: Process optimization and storage studies. Food and Bioproducts Processing, 99, 204-211. http://doi.org/10.1016/j.fbp.2016.05.002

Qureshi, A. A., Sami, S. A., \& Khan, F. A. (2002). Effects of stabilized rice bran, its soluble and fiber fractions on blood glucose levels and serum lipid parameters in humans with diabetes mellitus Types I and II. Journal of Nutritional Biochemistry, 13(3), 175-187. http://doi.org/10.1016/S0955-2863(01)00211-X

R Core Team. (2014). R: A Language and Enrionment for Statistical Computing, $R$ Foundation for Statisical Computing. Vienna. Retrieved from http://www.rproject.org/

Sun, G., Williams, P. N., Carey, A.-M., Zhu, Y. G., Deacon, C., Raab, A., ... Meharg, A. A. (2008). Inorganic arsenic in rice bran and its products are an order of magnitude higher than in bulk grain. Environmental Science and Technology, 42(19), 7542-7546. http://doi.org/10.1021/es801238p

The Lancet. (2016). Obesity: we need to move beyond sugar. The Lancet. http://doi.org/10.1016/S0140-6736(16)00091-X 
Tuncel, N. B., Yilmaz, N., Kocabiyik, H., \& Uygur, A. (2014). The effect of infrared stabilized rice bran substitution on B vitamins, minerals and phytic acid content of pan breads: Part II. Journal of Cereal Science, 59(2), 162-166. http://doi.org/10.1016/j.jcs.2013.12.005

Wang, J., Suo, G., de Wit, M., Boom, R. M., \& Schutyser, M. A. I. (2016). Dietary fibre enrichment from defatted rice bran by dry fractionation. Journal of Food Engineering, 186, 50-57. http://doi.org/10.1016/j.jfoodeng.2016.04.012

WHO. (2014). WHOCodex Alimentarius Commission-Geneva 14-18 July 2014. Retrieved from http://www.fao.org/news/story/en/item/238558/icode/

Williams, P. N., Villada, A., Deacon, C., Raab, A., Figuerola, J., Green, A. J., ... Meharg, A. A. (2007). Greatly enhanced arsenic shoot assimilation in rice leads to elevated grain levels compared to wheat and barley. Environmental Science and Technology, 41(19), 6854-6859. http://doi.org/10.1021/es070627i

Zhang, H.-J., Zhang, H., Wang, L., \& Guo, X.-N. (2012). Preparation and functional properties of rice bran proteins from heat-stabilized defatted rice bran. Food Research International, 47(2), 359-363. 
Table 1: Inorganic arsenic and DMA concentration in commercial rice bran, and

336 percentage of inorganic arsenic (median $(\min -\max )) . * \mathrm{RB}=$ Pure rice bran and $\mathrm{RB}$

337 WS $=$ Rice bran water-soluble.

\begin{tabular}{|c|c|c|c|c|}
\hline $\begin{array}{l}\text { Commercial } \\
\text { RB }\end{array}$ & $\mathrm{N}$ & i-As (mg/kg d.w.) & DMA (mg/kg d.w.) & i-As \% \\
\hline $\mathrm{RB}$ & 14 & $\begin{array}{c}0.561(0.376- \\
0.818)\end{array}$ & $\begin{array}{c}0.025(0.013- \\
0.032)\end{array}$ & $95.5(93.4-97.7)$ \\
\hline RB_WS & 2 & $\begin{array}{c}0.916(0.753- \\
1.079)\end{array}$ & $\begin{array}{c}0.041(0.028- \\
0.055)\end{array}$ & $95.6(95.0-96.3)$ \\
\hline RB_1 & 3 & $\begin{array}{c}0.668(0.664- \\
0.818)\end{array}$ & $\begin{array}{c}0.016(0.013- \\
0.018)\end{array}$ & $97.6(96.5-97.7)$ \\
\hline RB_2 & 4 & $\begin{array}{c}0.570(0.535- \\
0.626)\end{array}$ & $\begin{array}{c}0.025(0.024- \\
0.025)\end{array}$ & $95.6(95.4-95.9)$ \\
\hline RB_3 & 2 & $\begin{array}{c}0.533(0.504- \\
0.562)\end{array}$ & $\begin{array}{c}0.027(0.024- \\
0.030)\end{array}$ & $94.5(94.3-94.7)$ \\
\hline RB_4 & 1 & $\begin{array}{c}0.583(0.583- \\
0.583)\end{array}$ & $\begin{array}{c}0.027(0.027- \\
0.027)\end{array}$ & $94.8(94.8-94.8)$ \\
\hline RB_5 & 1 & $\begin{array}{c}0.561(0.561- \\
0.561)\end{array}$ & $\begin{array}{c}0.030(0.030- \\
0.030)\end{array}$ & $94.1(94.1-94.1)$ \\
\hline RB_6 & 2 & $\begin{array}{c}0.521(0.484- \\
0.559)\end{array}$ & $\begin{array}{c}0.030(0.029- \\
0.032)\end{array}$ & $93.5(93.4-93.6)$ \\
\hline RB_7 & 1 & $\begin{array}{c}0.376(0.376- \\
0.376)\end{array}$ & $\begin{array}{c}0.017(0.017- \\
0.017)\end{array}$ & $95.6(95.6-95.6)$ \\
\hline RB_8_WS & 1 & $\begin{array}{c}1.079(1.079- \\
1.079)\end{array}$ & $\begin{array}{c}0.055(0.055- \\
0.055)\end{array}$ & $95.0(95.0-95.0)$ \\
\hline RB_9_WS & 1 & $\begin{array}{c}0.753(0.753- \\
0.753)\end{array}$ & $\begin{array}{c}0.028(0.028- \\
0.028)\end{array}$ & $96.3(96.3-96.3)$ \\
\hline
\end{tabular}


Table 2: Arsenic speciation (i-As and DMA), and total calcium, copper, potassium, iron, manganese, phosphorus, sulfur, and zinc in raw and cooked rice bran according to the cooking time (median (min - max)).

\begin{tabular}{|c|c|c|c|c|c|c|}
\hline Water:Rice ratio & $\mathrm{N}$ & i-As (mg/kg) & DMA $(\mathrm{mg} / \mathrm{kg})$ & $\mathrm{Ca}(\mathrm{mg} / \mathrm{kg})$ & $\mathrm{Cu}(\mathrm{mg} / \mathrm{kg})$ & $\mathrm{K}(\mathrm{mg} / \mathrm{kg})$ \\
\hline Uncooked & 7 & $0.601(0.535-0.818)^{\mathrm{a}}$ & $0.025(0.013-0.030)^{\mathrm{a}}$ & $515.0(402.0-769.0)$ & $\begin{array}{c}10.60(9.350- \\
13.90)^{\mathrm{a}}\end{array}$ & $\begin{array}{c}15,300(14,000- \\
19,700)^{\mathrm{a}}\end{array}$ \\
\hline $75: 1$ & 7 & $0.374(0.277-0.526)^{b}$ & $0.012(0.006-0.020)^{\mathrm{b}}$ & $379.0(299.0-787.0)$ & $\begin{array}{c}6.980(6.380- \\
10.00)^{\mathrm{b}}\end{array}$ & $\begin{array}{c}8,430(8,030- \\
12,000)^{\mathrm{b}}\end{array}$ \\
\hline $150: 1$ & 7 & $0.212(0.032-0.376)^{\mathrm{c}}$ & $0.007(0.003-0.014)^{b}$ & $489.0(228.0-661.0)$ & $\begin{array}{c}6.860(5.090- \\
11.10)^{\mathrm{b}}\end{array}$ & $\begin{array}{c}6,720(4,040- \\
10,800)^{\mathrm{b}}\end{array}$ \\
\hline $300: 1$ & 4 & $0.167(0.028-0.260)^{\mathrm{c}}$ & $0.006(0.003-0.011)^{b}$ & $445.5(389.0-567.0)$ & $\begin{array}{c}6.195(5.850- \\
9.890)^{\mathrm{b}}\end{array}$ & $\begin{array}{c}4,805(1,890- \\
10,500)^{\mathrm{b}}\end{array}$ \\
\hline$p$-value & & $<0.001$ & $<0.001$ & 0.543 & 0.002 & $<0.001$ \\
\hline Water:Rice ratio & $\mathrm{N}$ & $\mathrm{Fe}(\mathrm{mg} / \mathrm{kg})$ & $\mathrm{Mn}(\mathrm{mg} / \mathrm{kg})$ & $\mathrm{P}(\mathrm{mg} / \mathrm{kg})$ & $\mathrm{S}(\mathrm{mg} / \mathrm{kg})$ & $\mathrm{Zn}(\mathrm{mg} / \mathrm{kg})$ \\
\hline Uncooked & 7 & $84.90(79.90-131.0)$ & $276.1(214.7-417.1)$ & $\begin{array}{c}18,679(17,131- \\
20,703)^{\mathrm{a}}\end{array}$ & $1,530(1,340-1,830)$ & $60.60(46.00-73.50)$ \\
\hline $75: 1$ & 7 & $71.50(62.30-91.40)$ & $291.2(231.4-408.6)$ & $\begin{array}{c}16,238(14,649- \\
17,376)^{\mathrm{ab}}\end{array}$ & $1,390(1,250-1,840)$ & $52.90(38.60-56.00)$ \\
\hline $150: 1$ & 7 & $75.50(53.40-149.0)$ & $303.5(233.5-427.1)$ & $\begin{array}{c}14,776(11,064- \\
17,237)^{\mathrm{b}}\end{array}$ & $1,450(1,090-2,120)$ & $54.30(35.90-84.50)$ \\
\hline $300: 1$ & 4 & $67.25(51.00-118.0)$ & $382.8(319.4-424.8)$ & $\begin{array}{c}14,494(11,151- \\
16,536)^{\mathrm{b}}\end{array}$ & $1,235(1,010-2,090)$ & $48.50(34.50-77.40)$ \\
\hline$p$-value & & 0.504 & 0.362 & $<0.001$ & 0.635 & 0.601 \\
\hline
\end{tabular}


Figure 1: Inorganic arsenic and DMA concentration in rice bran, and removal percentage according to water-to-rice bran ratio.
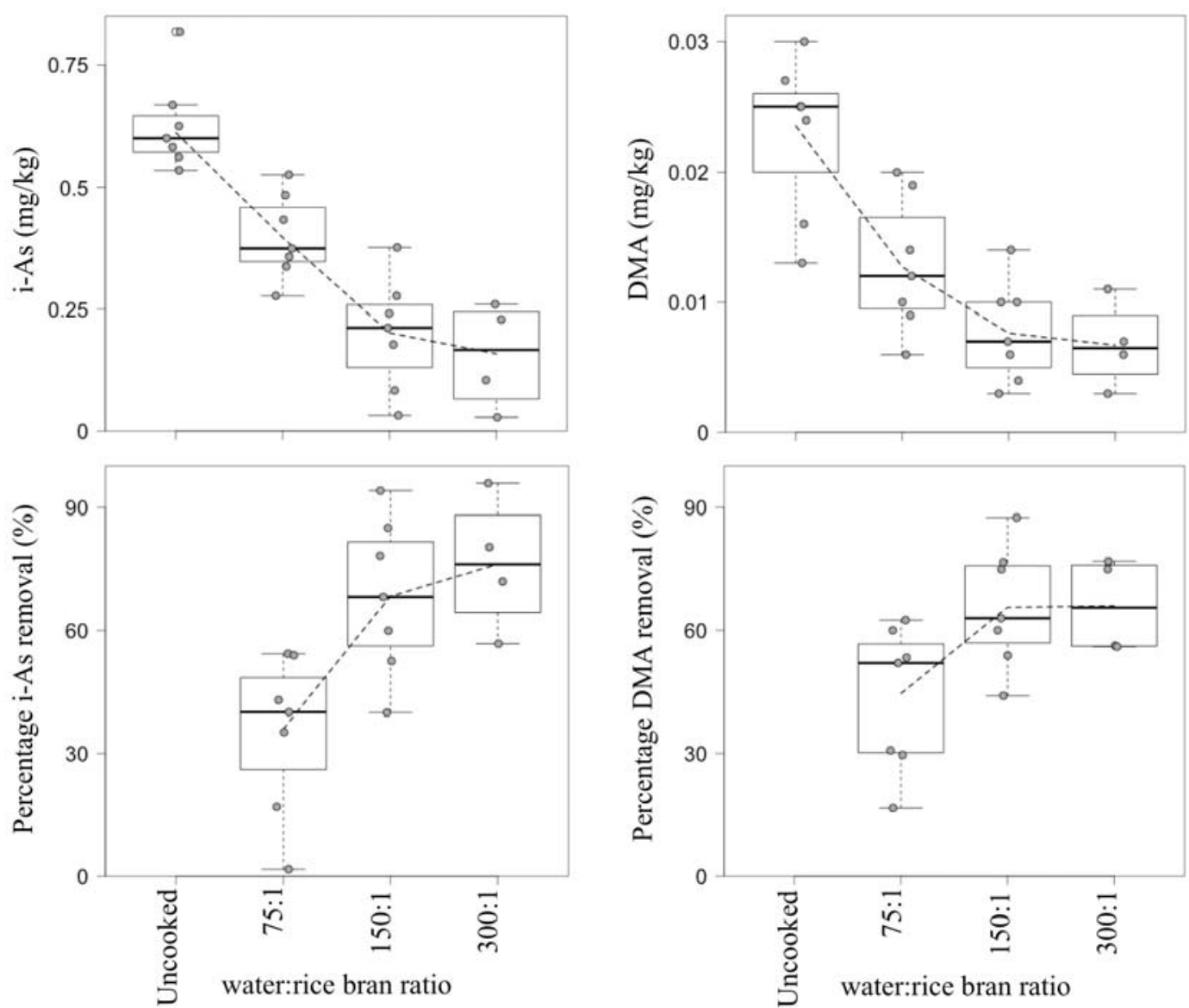
Figure 2: Percentage of compositional variation according to the water-to-rice bran ratio. Each point at 75:1 and 150:1 ratios shows the median percentage obtained from 7 rice bran samples, respectively. Each point at 300:1 ratio shows the median percentage obtained from 4 rice bran samples.

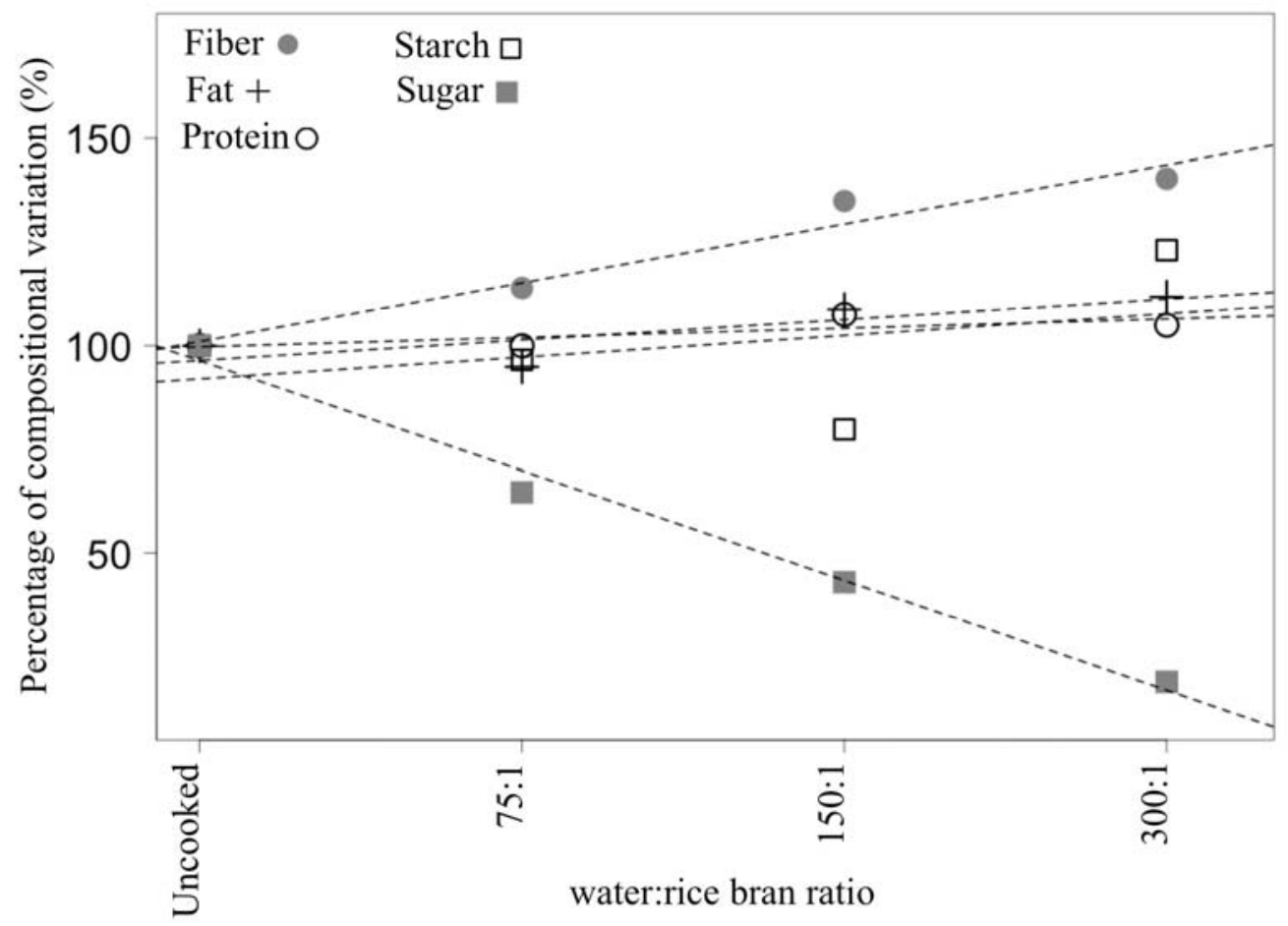

